\title{
Locus of control: Upaya untuk menurunkan social loafing
}

\section{Arief Sumantri ${ }^{*}$, Iqlima Pratiwi ${ }^{2}$}

Fakultas Psikologi, Universitas Airlangga, Indonesia

\begin{tabular}{l}
\hline Info Artikel \\
\hline Sejarah Artikel: \\
Diterima \\
I2 Maret 2019 \\
Direview \\
I0 September 2019 \\
Disetujui \\
07 Februari 2020 \\
Dipublikasikan \\
27 Februari 2020 \\
\hline Keywords: \\
Group tasks, \\
Locus of control, \\
Social loafing.
\end{tabular}

\begin{tabular}{l} 
Abstrak \\
\hline Objektif: Social loafing merupakan fenomena menurunnya performansi \\
(upaya/usaha) individu didalam pengerjaan tugas berbasis kelompok, hal yang tentu \\
saja akan berdampak pada kinerja serta kepuasan kelompok. Penelitian ini ditujukan \\
untuk mengetahui pengaruh locus of control, baik secara internal maupun eksternal \\
terhadap social loafing dalam penyelesaian tugas kelompok.
\end{tabular}

Metode: Penelitian ini menggunakan pendekatan kuantitatif. Pengambilan sampel menggunakan non-probability sampling dengan teknik accidental sampling pada populasi mahasiswa jurusan kependidikan (calon guru), dengan jumlah keseluruhan partisipan sebanyak 147 mahasiswa (45 tryout skala, 102 uji hipotesis). Pengukuran tiap variabel memodifikasi konstruk skala dari penelitian sebelumnya, yang merujuk pada Levenson untuk locus of control dan Latane untuk social loafing. Kemudian dianalisis menggunakan uji regresi linier.

Temuan: Locus of control internal dalam penelitian ini terbukti mampu menurunkan social loafing (sig. 0,000), dengan Nilai R Square (kontribusi pengaruh) pada tabel koefisien determinasi senilai $0,21 \mathrm{I}$ atau sebesar $21,1 \%$, sedangkan Locus of control eksternal tidak memberikan kontribusi pengaruh sama sekali.

Kesimpulan: Locus of control internal terbukti dapat menurunkan kecenderungan social loafing pada mahasiswa, sedangkan Locus of control eksternal tidak memberikan kontribusi pengaruh sama sekali, bahkan tidak berkorelasi dengan social loafing.

\section{Locus of control: Efforts to reduce social loafing}

Objectives: Social loafing is a phenomenon of decreased performance (efforts / efforts) of individuals in the work of group-based tasks, which of course will have an impact on performance and group satisfaction. This study aimed to determine the effect of locus of control, both internally and externally on social loafing in group task completion.

Method: This study uses a quantitative approach. Sampling using non-probability sampling with accidental sampling technique in the population of students majoring in education (prospective teachers), with a total number of participants as many as 147 students (45 tryout scale, 102 hypothesis testing). The measurement of each variable modifies the scale construct of previous research, which refers to Levenson for locus of control and Latane for social loafing. Then analyzed using a linear regression test.

Findings: Internal locus of control in this study proved to be able to reduce social loafing (sig. 0,000), with $R$ Square value (influence contribution) in the determination coefficient table of 0.211 or $21.1 \%$, while external locus of control did not contribute to the effect at all.

Conclusions: Internal locus of control is proven to reduce the tendency of social loafing in students, while external locus of control does not contribute to the influence at all, it does not even correlate with social loafing.

*Alamat korespondensi: Universitas Airlangga Kampus B Kecamatan Gubeng Kota Surabaya Jawa Timur 60286 aripsumantril42@gmail.com 


\section{Pendahuluan}

"Berat sepikul, ringan sejinjing", merupakan satu dari sekian kalimat pembakar semangat bagi para mahasiswa, ketika dihadapkan pada tugas-tugas yang harus terselesaikan secara berkelompok. Secara eksplisit, makna dari falsafah tersebut mengisyaratkan mudah atau sulitnya pekerjaan yang dipikul kelompok, akan menjadi ringan jika tugas itu diselesaikan secara bersama-sama. Penelitian yang dilakukan Heller, Keith \& Anderson ditahun 1992, telah mengungkapkan bahwa pemberian tugas kelompok pada individu secara signifikan membuat kemampuan mahasiswa didalam penyelesaian masalah akan semakin meningkat. Penelitian Webb (1995) juga menyimpulkan demikian, adanya tugas kelompok, membuat individu mendapatkan pengetahuan baru didalam dirinya, selain itu individu juga dapat belajar menjalin hubungan kerja sama yang baik, sekaligus memaksimalkan performansi serta pencapaian output bagi dirinya, fenomena yang disebut Henry Allport sebagai efek social facilitation, atau terkadang disebut audience effect, dimana performansi individu mengalami peningkatan disebabkan oleh kehadiran individu lain.

Hal berbeda kemudian dikemukakan Latane, Williams \& Harkins (1979) perihal kehadiran individu lain didalam kelompok, setelah sebelumnya mereplikasi eksperimen yang pernah dilakukan oleh Max Ringelmann (19/3). Perihal eksperimen Ringelmann, juga dikenal dengan istilah Ringelmann effect, yaitu penurunan produktifitas pada individu didalam kelompok disebabkan oleh jumlah anggota yang bertambah (Latane et al., 1979; Kravitz, \& Martin, 1986), dalam group berisi dua partisipan tercatat presentase performansi masih sebesar $93 \%$, digroup trio menurun menjadi $85 \%$, hingga dikelompok yang berisi 8 partisipan, performansi tercatat hanya sebesar 49\% (dalam Singh, Wang \& Zhu, 2018). Penelitian Ringelman ini belum membedakan penurunan kinerja kelompok terjadi karena individu menurunkan usaha/upayanya sendiri atau karena kordinasi yang buruk didalam kelompok. Setelahnya, Ingham, Levinger, Graves, \& Peckham (1974) juga mencoba mereplikasi penelitian "the rope-pulling" Ringelmann, dengan membagi partisipan kedalam dua kelompok, kelompok pertama berisi peserta yang kesemuanya real secara bersama sama menarik tali, hasilnya kelompok pertama menunjukkan penurunan kinerja terbesar dibanding kelompok kedua ketika jumlah anggota kelompok ditingkatkan, untuk kelompok kedua hanya berisi satu peserta real dengan kondisi mata tertutup, selebihnya adalah asisten peneliti. Peneliti membuatnya percaya bahwa dia sedang menarik tali tersebut beramai-ramai dengan peserta lain, yang sebenarnya asisten peneliti hanya berpura pura menarik tali, dan hasilnya juga menemukan bahwa performa individu tetap menurun, dikarenakan kelompok kedua terisolasi dari efek kordinasi (teman peserta secara fisik tidak menarik tali) maka Ingham et al.,(1974) menyimpulkan bahwa faktor motivasi lebih memungkinkan menjadi penyebab ketimbang kordinasi terhadap terjadinya penurunan performa individu. Melalui replikasi serta modifikasi, Latane et al., (1979) melakukan eksperimen dengan gaya yang berbeda, mereka tidak menggunakan tali, mereka membuat partisipan berteriak dan bertepuk tangan dengan sekeras mungkin, baik secara sendiri maupun bersama individu lainnya.

Menurunnya usaha/upaya individu dalam pengerjaan tugas secara berkelompok ketimbang saat melakukannya sendiri, yang akhirnya membuat kinerja kelompok menurun, adalah definisi dari fenomena social loafing, dicetuskan Latane et al., (1979) setelah eksperimen mereka selesai dilakukan, dalam hal ini mereka berpendapat bahwa kelompok bisa menjadi penghambat produktifitas dari individu, sehingga individu cenderung mengurangi upayanya didalam pengerjaan tugas. Pendapat Karau \& Williams (1993) mengindikasikan hal yang sama, social loafing terjadi karena individu cenderung mengurangi motivasi serta usahanya ketika bekerja bersama-sama (collective) didalam kelompok, berbeda ketika individu itu bekerja sendiri, dalam hal ini individu dapat diasumsikan merasa yakin bahwa tugas yang diberikan dapat dikerjakan oleh angota kelompok yang lain. Hasil penelitian Shih, Shao \& Wang (2017) pada sejumlah karyawan perusahaan menunjukkan sosial loafing membuat tingkat kreativitas para karyawan menurun, sesuai dengan pendapat Hart, Karau, Stasson \& Kerr (2004), bahwa para pelaku social loafing cenderung memiliki motivasi berprestasi (achievement motivation) yang rendah. 
Social Impact Theory (198I) dari Bibb Latane, menjelaskan fenomena social loafing dalam dua dimensi teoritis, yaitu dilution effect dan immediacy gap (dalam Chidambaram \& Tung, 2005). Pertama, efek dilusi (dilution effect), dimana individu merasa kontribusinya pada kelompok sangatlah minim (kecil), juga bisa disebabkan individu merasa kurang bahkan tidak mendapat penghargaan didalam kelompok.kedua, kesenjangan dalam kedekatan (immediacy gap), dimana individu merasa terasing dari kelompok, pada akhirnya membuat dia semakin menjauh dari tugas yang dibebankan padanya.

Berbagai hasil riset menunjukkan social loafing nampaknya lebih cenderung memberikan dampak negatif terhadap keefektifan individu, terlebih pada kelompok, yang tentu akan sangat berpengaruh pada performansi, kehadiran, dan kepuasan kelompok. Hasil penelitian Ying, Jiang, Peng \& Lin (2014), menunjukkan bahwa individu dengan tingkat social loafing tinggi, memiliki tingkat performansi yang buruk saat pengerjaan tugas kelompok. Penelitian Zahra, Eliana, Budiman \& Novliadi (2015) menunjukkan bahwa kecenderungan terjadinya social loafing, membuat prestasi akademik menjadi rendah, bahkan lebih dari itu, dampak kerugian lainnya selain menurunkan potensi serta kohesivitas kelompok, ternyata social loafing juga dapat memunculkan perasaan iri hati didalam diri individu (Duffy \& Shaw, 2000), beberapa hasil riset ini semakin memperkuat kesimpulan bahwa fenomena social loafing memang tidak hanya berakibat negatif pada kelompok, tetapi juga pada pelakunya sendiri. Penyebab social loafing diidentifikasi terjadi selain karena motivasi (lost motivation), juga disebabkan karena kurangnya kontrol dan kordinasi didalam kelompok (dalam Alnuaimi, Robert, \& Maruping, 2009).

Tahun 2017, Deborah S \& Eliana mencoba mengkorelasikan fenomena social loafing dengan locus of control didalam penyelesaian tugas berbasis kelompok. Penelitian yang melibatkan partisipan sebanyak 300 mahasiswa ini ternyata menunjukkan signifikansi yang positif, terjadi korelasi antara social loafing dan locus of control, semakin internal locus of control pada individu maka semakin rendah kecenderungan untuk mengurangi usaha/upaya saat bekerja didalam kelompok. Locus of control pertama kali dikembangkan oleh Julian B. Rotter, seorang ahli social learning theory pada tahun 1954, definisi Locus of control dari Rotter adalah sejauh mana keyakinan didalam diri individu mengenai sumber penguatan (reinforcement) didalam hidupnya, apakah kekuatan tersebut berasal dari dalam dirinya sendiri, atau bergantung pada tindakan individu lain maupun pengaruh yang berada diluar kendalinya (Rotter, 1966), contohnya nasib dan takdir. Locus of control menjadi faktor psikologis yang sangat berpengaruh terhadap motivasi, individu dengan locus of control internal tinggi percaya bahwa peristiwa didalam hidupnya disebabkan karena tindakannya sendiri, ambil contoh ketika siswa menerima hasil ujian, individu locus of control internal yang kuat akan lebih cenderung menyalahkan dirinya sendiri ketika hasil yang dicapai tidak sesuai keinginan, begitupun sebaliknya, akan memuji dirinya berkat usahanya sendiri jika hasilnya sesuai dengan keinginan. Sedangkan individu dengan locus of control eksternal kuat akan cenderung memuji atau menyalahkan faktor diluar dirinya, semisal sahabat atau guru, atau bahkan karena nasib.

Hanna Levenson (198I) kemudian mengembangkan teori locus of control Rotter dalam orientasi pengelompokan internal dan eksternal, yang dikenal dengan istilah IPC-locus of control. Orientasi Internal terdiri dari satu faktor, yaitu internality (I), merupakan keyakinan pada individu bahwa kejadian-kejadian didalam hidupnya lebih ditentukan oleh kemampuan dan usahanya sendiri.Orientasi External terdiri dari dua faktor, yaitu: powerfull-others $(P)$, merupakan keyakinan individu bahwa kejadian-kejadian didalam hidupnya lebih ditentukan oleh orang-orang disekitarnya yang lebih memiliki power. chance $(C)$, keyakinan pada individu bahwa kejadian-kejadian didalam hidupnya lebih ditentukan oleh takdir, nasib, atau keberuntungan.

Locus of control telah banyak diuji oleh para peneliti diberbagai bidang psikologi, misalnya Richard Kahoe (1974) dalam psikologi agama. Wallston, Wallston, Kaplan \& Maides (1976) dalam bidang psikologi kesehatan. Allen, Weeks \& Moffitt (2005) dalam psikologi industri \& organisasi, kemudian dalam bidang psikologi politik salah satunya dilakukan oleh Deutchman (1985), bahkan dua paradigma antara psikologi kesehatan dan psikologi agama tergabung dalam penelitian yang 
dilakukan Holt, Clark, Kreuter \& Rubio (2003), saat mencoba mengukur locus of control kesehatan spritual. Sedangkan dibidang psikologi pendidikan, locus of control mendapatkan banyak sumbangan dari riset Cassandra B. Whyte (1977), yang telah banyak mendapat pengakuan dalam publikasi penelitian dibidang pendidikan. Khusus pada kecenderungan orientasi locus of control, terlihat dalam beberapa riset seperti penelitian dari Khir, Redzuan, Hamsan \& Shahrimin (2015), dimana para siswa dengan tingkat prestasi akademik yang lebih tinggi cenderung memiliki locus of control internal yang tinggi, kemudian hasil penelitian Abzani \& Leonard (2017) terkait pengaruh locus of control pada kemampuan pemecahan masalah matematika juga menunjukkan perbedaan signifikan, siswa dengan locus of control internal yang tinggi memiliki tingkat pemecahan matematika yang lebih baik. Sebaliknya dari hasil riset Fini \& Yousefzadeh (20II), menyimpulkan bahwa locus of control eksternal membuat achievement motivation siswa menjadi rendah. Hasil yang sama juga diperoleh dari penelitian Howerton, Enger, \& Cobbs (1993), individu dengan tingkat locus of control eksternal yang tinggi, menunjukkan motivasi berprestasi yang rendah.

Sehubungan dengan fenomena social loafing, hasil penelitian Deborah S \& Eliana (2017) telah menunjukkan hubungan positif antara keduanya, semakin internal locus of control pada individu, maka akan semakin rendah kecenderungan untuk terjadinya social loafing, sehingga penelitian ini dimaksudkan dan ditujukan untuk menguji variabel locus of control, baik secara internal maupun eksternal sebagai prediktor pada social loafing. Seperti telah diuraikan diawal, oleh para peneliti (misalnya Heller et al., 1992; Webb, 1995) kerja kelompok diyakini akan memberikan dampak positif buat individu, tidak hanya sekedar meningkatkan performansi, tetapi juga membantu meningkatkan hubungan relasi yang baik, sebaliknya social loafing justru akan menurunkan performansi individu mencakup produktifitas kinerja kelompok. Selain menyadari efek dari social loafing terhadap individu dan kelompok, uji hipotesis ini juga dilakukan dengan melihat potensi dari variabel locus of conrol, bahkan beberapa riset perihal locus of control mengindikasikan locus of control internal banyak memberikan efek positif. Manfaat dari penelitian ini sendiri, seperti yang telah tercantum didalam penggalan judul, diharapkan agar dapat menjadi satu upaya untuk menurunkan social loafing, yang oleh Latane et al.,(1974 hal. 83I), social loafing dapat dianggap sebagai penyakit sosial (social disease) mengingat konsekuensi negatif yang ditimbulkan, tidak hanya pada individu dan kelompok, tetapi juga terhadap institusi sosial dan masyarakat.

Tujuan penelitian ini adalah untuk mengetahui pengaruh locus of control baik secara internal maupun eksternal terhadap social loafing pada mahasiswa dalam penyelesaian tugas secara kelompok. Manfaat penelitian ini diharapkan dapat menjadi sumber referensi khususnya dalam kajian psikologi.

\section{Metode}

Peneliti menggunakan pendekatan kuantitatif untuk melakukan pembuktian pada hipotesis yang telah ditentukan. Pengambilan sampel menggunakan non-probability sampling dengan teknik accidental sampling. Populasi berasal dari salah satu Universitas Negeri di Kota Malang, tepatnya Fakultas Ilmu Pendidikan Jurusan Kependidikan Sekolah Dasar \& Prasekolah (KSDP) Program Studi PGSD, dengan total keseluruhan partisipan sebanyak I 47 mahasiswa, 45 digunakan sebagai uji coba (try out) skala, dan 102 untuk uji hipotesis, dengan kriteria partisipan merupakan mahasiswa berstatus aktif. Pengumpulan data menggunakan skala psikologi berupa skala, berisi seperangkat pernyataan tertulis. Pengukuran locus of control internal memodifikasi skala yang dikonstruk Ismail (2016) berdasarkan pada pengelompokkan orientasi locus of control dari Levenson, jumlah Item sebanyak 26 Item, terdiri dari 10 Item untuk locus of control internal (contoh: Saya berhasil mendapat nilai yang tinggi dalam perkuliahan karena usaha keras yang saya lakukan sendiri) dan 16 Item untuk locus of control eksternal (contoh: Kesuksesan yang saya raih karena ada campur tangan dari orang lain), dengan tingkat reliabilitas sebesar 0,728. Sedangkan pengukuran social loafing memodifikasi skala yang dikonstruk Sisilia (2016) berdasarkan teori social loafing dari Latane yang terdiri dari dimensi dilution effect dan immediacy gap, jumlah Item sebanyak 13 Item (contoh: saya tidak begitu menonjol ketika bekerja di dalam kelompok) dengan tingkat reliabilitas Item sebesar 0,899. 
Hasil uji coba alat ukur beberapa Item dinyatakan gugur di setiap variabel, berikut dibawah ini tabel hasil uji validitas dan reliabilitas.

Tabel I.

Hasil Uji Coba Alat Ukur (Try Out)

\begin{tabular}{lllll}
\hline Variabel & $\begin{array}{l}\text { Item Favorable } \\
\text { Valid }\end{array}$ & Gugur & \multicolumn{2}{l}{ Item Unfavorable } \\
& Valid & Gugur \\
\hline Loc Internal & $5,7,11,13,22,25$ & 3 & 8 & 17,23 \\
Loc Eksternal & $1,15,2,9$ & $14,16,19,20,21,24$ & $10,4,6,12,18$ & \\
Social loafing & $1,2,4,5,10,12,13$ & & $3,6,7,8,9$ & 11 \\
Jumlah & $\mathbf{I 7}$ & $\mathbf{7}$ & $\mathbf{I I}$ & $\mathbf{3}$ \\
\hline
\end{tabular}

Total Item valid yang akan digunakan sebanyak 28 Item, terdiri dari 7 Item Loc internal, 9 Item Loc eksternal dan 12 Item social loafing, Item valid diperoleh berdasarkan hasil uji validitas dan fiture scale if item deleted dalam SPSS. Nilai reliabilitas dari ke 3 alat ukur berdasarkan hasil uji coba senilai 0,60 I untuk Loc internal, 0,6II untuk Loc eksternal dan 0,835 untuk social loafing. Item-Item valid yang didapatkan kemudian digunakan dalam angket kuisioner yang ditujukan untuk menguji hipotesis. Analisis data menggunakan uji regresi linier untuk mengetahui seberapa besar kontribusi pengaruh locus of control baik secara internal maupun external terhadap social loafing.

\section{Hasil}

Pengambilan data dilakukan sebanyak dua kali, yang pertama untuk uji coba alat ukur (try out) dengan total partisipan sebanyak 45 mahasiswa. Kedua dilakukan untuk menguji hipotesis, dengan total partisipan sebanyak 102 mahasiswa.

\section{Tabel 2.}

Hasil Deskripsi Subjek Penelitian

\begin{tabular}{lll}
\hline Deskripsi Subjek & $\mathbf{N}$ & Persentase \\
\hline $\begin{array}{l}\text { Jenis Kelamin } \\
\text { Laki-Laki }\end{array}$ & 22 & $21,6 \%$ \\
Perempuan & 80 & $78,4 \%$ \\
Range Usia & & \\
18 & 6 & $5,9 \%$ \\
19 & 26 & $25,5 \%$ \\
20 & 37 & $36,3 \%$ \\
21 & 25 & $24,5 \%$ \\
22 & 8 & $7,8 \%$ \\
Susana Kelompok & & \\
Sangat Suka & 7 & $6,9 \%$ \\
Suka & 77 & $75,5 \%$ \\
Relatif & 13 & $12,7 \%$ \\
Kurang Suka & 2 & $2 \%$ \\
Tidak Suka & 3 & $9 \%$ \\
\hline
\end{tabular}

Nilai pada tabel frequency menunjukkan jumlah mahasiswa dengan jenis kelamin laki-laki sebanyak 22 mahasiswa $(21,6 \%)$, perempuan sebanyak 80 mahasiswa $(78,4 \%)$, dengan masing-masing range usia 18 tahun sebanyak 6 mahasiswa (5,9\%), 19 tahun sebanyak 26 mahasiswa (25,5\%), 20 tahun sebanyak 37 mahasiswa (36,3\%), 2 I tahun sebanyak 25 mahasiswa (24,5\%), dan 22 tahun sebanyak 8 mahasiswa (7,8\%). Kemudian untuk tingkat afeksi saat pengerjaan tugas kelompok, sebanyak 7 mahasiswa $(6,9 \%)$ merasa sangat suka, 77 mahasiswa $(75,5 \%)$ sebatas suka, I3 mahasiswa $(12,7 \%)$ menjawab relatif, 2 mahasiswa $(2 \%)$ merasa kurang suka, \& sebanyak 3 mahasiswa $(2,9 \%)$ menjawab tidak suka. Sebelum melakukan kategorisasi pada setiap variabel, terlebih dahulu 
dilakukan analisis deskriptif untuk mengetahui nilai rata-rata (mean) pada setiap variabel, berikut dibawah ini hasil dari analisis deskriptif.

\section{Tabel 3.}

Hasil Analisis Deskriptif dan Korelasi antar Variabel

\begin{tabular}{lllllll}
\hline Variabel & $\mathbf{I}$ & $\mathbf{2}$ & $\mathbf{3}$ & $\mathbf{4}$ & $\mathbf{5}$ & $\mathbf{6}$ \\
\hline I. Social Loafing & - & & & & & \\
2. Loc Internal & $-0.459^{* *}$ & - & & & & \\
3. Loc External & 0.109 & 0.359 & - & & & \\
4. Jenis Kelamin & $-0.264^{* *}$ & 0.052 & -0.125 & - & & \\
5. Usia & -0.167 & $0.199^{*}$ & -0.093 & 0.062 & - & \\
6. Suasana Kelompok & -0.084 & 0.057 & 0.079 & -0.037 & 0.115 & - \\
Mean & 23.90 & 22.10 & 22.54 & 1.78 & 20.03 & 3.8137 \\
Standard Deviation & 3.104 & 1.917 & 2.328 & 0.413 & 1.029 & 0.71380 \\
Minimum & 16 & 17 & 17 & 1 & 18 & 1.00 \\
Maksimum & 32 & 27 & 29 & 2 & 22 & 5.00 \\
\hline$N=102 * 0.05 * 0.017$
\end{tabular}

Tabel deskriptif menunjukkan nilai mean Social loafing senilai 23.90, Loc internal senilai 22.10, dan Loc eksternal senilai 22.54, dimana variabel social loafing berkorelasi dengan Loc Internal $(p=0,000)$ dan jenis kelamin $(p=0,007)$, kemudian Loc internal berkorelasi dengan usia $(p=0,045)$. Sebelumnya telah dilakukan uji normalitas data menggunakan Non Parametric K-S, dan menunjukkan nilai sig. sebesar 0,200 lebih besar dari 0,05 artinya data didalam penelitian ini berdistribusi normal, sehingga untuk proses kategorisasi pada setiap variabel penelitian menggunakan angka Mean $(\mu)$ sebagai acuan, untuk kategorisasi peneliti hanya menggunakan 2 jenjang yaitu "Tinggi” dan "Rendah", berikut dibawah ini hasil kategorisasi dari setiap variabel.

Tabel 4.

Kategorisasi Skala

\begin{tabular}{llll}
\hline Variabel & Kategorisasi & Jumlah & Persentase \\
Internal & Tinggi & 35 & $34.3 \%$ \\
& Rendah & 67 & $65.7 \%$ \\
External & Total & 102 & $100 \%$ \\
& Tinggi & 48 & $47.1 \%$ \\
Social Loafing & Rendah & 54 & $52,9 \%$ \\
& Total & 102 & $100 \%$ \\
& Tinggi & 61 & $59.8 \%$ \\
& Rendah & 41 & $40.2 \%$ \\
\hline
\end{tabular}

Nilai pada tabel frequency menunjukkan jumlah mahasiswa dengan tingkat Loc internal tinggi sebanyak 35 mahasiswa (34,3\%), dan yang rendah sebanyak 67 mahasiswa $(65,7 \%)$, sedangkan eksternal menunjukkan sebanyak 48 mahasiswa (47.1\%) memiliki tingkat Loc ekternal tinggi dan yang rendah sebanyak 54 mahasiswa (52,9\%). Jumlah mahasiswa dengan tingkat social loafing tinggi sebanyak 6 I mahasiswa $(59,8 \%)$, dan yang rendah sebanyak 4 I mahasiswa $(40,2 \%)$. Setelah uji normalitas dan kategorisasi, kemudian dilakukan uji asumsi (uji linearitas dan heteroskedastisitas) sebelum melakukan uji hipotesis. Nilai sig. Linearity Loc internal senilai 0,00 I lebih kecil dari 0,050 artinya terdapat hubungan yang linear antara Loc internal dengan social loafing, sedangkan untuk Loc eksternal senilai 0,225 lebih besar dari 0,050 artinya tidak terdapat hubungan yang linear antara Loc eksternal dengan social loafing, sehingga untuk uji hipotesis hanya akan dilakukan pada Loc internal. Kemudian untuk Nilai sig. Loc internal pada tabel heterokedastitas menunjukkan nilai sebesar 0,685 lebih besar dari 0,050 artinya tidak terjadi heterokedastitas melainkan homoskedasitas. 
Tabel 5.

Hasil Uji Regresi Linear

\begin{tabular}{|c|c|c|c|c|c|}
\hline \multirow[b]{2}{*}{ Model } & \multicolumn{2}{|c|}{ Koefisien Tidak Standar } & \multicolumn{3}{|c|}{ Koefisien Standar } \\
\hline & B & Std. Error & Beta & $\mathbf{t}$ & Sig \\
\hline $\begin{array}{ll}\text { I } & \text { (Konstan) } \\
& \text { Internal }\end{array}$ & $\begin{array}{l}40.342 \\
-.744\end{array}$ & $\begin{array}{l}3.190 \\
.144\end{array}$ & -.459 & $\begin{array}{l}12.644 \\
-5.172\end{array}$ & $\begin{array}{l}.000 \\
.000\end{array}$ \\
\hline
\end{tabular}

Nilai signifikansi pada tabel menunjukkan nilai 0,000 lebih kecil dari 0,05 sehingga Loc internal secara signifikan berpengaruh terhadap social loafing, dengan tingkat kepercayaan (level confidence) minimal di $95 \%$. Nilai angka konstan dari unstandardized coefficients menunjukkan bahwa jika tidak ada locus of control internal maka nilai konsisten social loafing adalah sebesar 40,342. Nilai angka koefisien regresi senilai $-0,744$ menunjukkan setiap penambahan $1 \%$ pada locus of control internal akan menurunkan social loafing sebesar 0,744 . Nilai negatif $(-0,744)$ yang terdapat pada koefisien regresi menggambarkan hubungan terbalik antara Loc internal dengan social loafing pada Mahasiswa, dimana jika Loc internal mengalami peningkatan maka social loafing akan menurun.

Tabel 6.

Hasil Koefisien Determinasi

\begin{tabular}{lllll}
\hline Model & $\mathbf{R}$ & R Square & $\begin{array}{l}\text { Adjusted } \mathbf{R} \\
\text { Square }\end{array}$ & $\begin{array}{l}\text { Std. Error of the } \\
\text { Estimate }\end{array}$ \\
\hline I & .459 & .211 & .203 & $2.77 I$ \\
\hline
\end{tabular}

Nilai R Square pada tabel senilai 0,2II menunjukkan kontribusi pengaruh locus of control internal terhadap social loafing adalah sebesar 21 , I\% sedangkan sisanya $78,9 \%$ dipengaruhi oleh variabel lain di luar dari variabel dalam penelitian ini.

\section{Pembahasan}

Hasil dari uji hipotesis menunjukkan Loc internal terbukti dapat menurunkan social loafing mahasiswa dalam penyelesaian tugas kelompok, hasil penelitian ini memperkuat penelitian Deborah S \& Eliana (2017) perihal hubungan antara Loc internal dan social loafing. Latane et al., (1979) telah mengungkapkan beberapa faktor yang mempengaruhi social loafing, antara lain attribution and equity (individu menganggap anggota lain tidak berkompeten sehingga tidak perlu untuk mengeluarkan usaha yang lebih keras), submaximal goal setting (tujuan dari kelompok tidak ditekankan dengan maksimal), lessened contingency between input and output outcome (individu menganggap usaha yang dikeluarkannya tidak akan setara dengan apa yang akan didapatkannya), dan tentu saja group size (jumlah anggota kelompok). Selain itu juga ada group evaluation (tidak ada sosok yang mengevalusi hasil pekerjaan kelompok, baik dari diri sendiri mauupun dari anggota kelompok yang lain) dari Harkins \& Szymanski (1989), individualism-collectivism (individu pada budaya kolektivis lebih berorientasi pada tujuan kelompok) dari Earley (1989), kemudian expected coworker performance (individu merasa usaha dari anggota kelompok yang lain akan tinggi sehingga tidak perlu mengeluarkan usaha yang lebih) dan achievement motivation (dimana individu dengan motivasi berprestasi rendah lebih cenderung melakukan loafing) dari Hart et al., (2004), lalu group cohesion (anggota kelompok saling tidak mengenal) dari Hoigaard, Tofteland \& Ommundsen (2006), dan distributive justice (persepsi individu bahwa hasil kerja dari setiap anggota kelompok tidak akan mendapatkan reward yang sama) dari Piezon \& Ferree (2008).

Kategorisasi skala social loafing menunjukkan sebanyak $6 \mathrm{I}$ mahasiswa $(59 \%)$ memiliki tingkat social loafing yang tinggi dalam penyelesaian tugas secara berkelompok, untuk memahami hal tersebut, Clark \& Baker (20II) mengungkapkan beberapa alasan penyebab mahasiswa melakukan social loafing, diantaranya terjadi karena individu tidak memiliki keinginan yang kuat untuk mengerjakan bagian tugasnya dalam kelompok, tidak memiliki ekspektasi tinggi terhadap tugas kelompok sehingga tidak maksimal dalam pengerjaan, mengganggap tugas kelompok hanya sebagai sarana untuk menghabiskan waktu luang sehingga tidak perlu bekerja maksimal, persepsikan bahwa nilai 
yang akan diberikan pada setiap anggota kelompok adalah sama, tidak merasakan tekanan akan mendapat nilai yang jelek dalam tugas kelompok. Selain itu juga bisa terjadi karena individu membandingkan dirinya dengan anggota kelompok lain, membuatnya merasa tidak memiliki kemampuan yang baik. Jumlah anggota dalam kelompok juga menetukan seberapa produktif individu dalam penyelesaian tugas, hasil kategorisai suasana kelompok menunjukkan sebanyak 2 mahasiswa "kurang suka" dan 3 mahasiswa "tidak suka" dengan penyelesaian tugas secara kelompok, hal yang banyak dikeluhkan mahasiswa adalah keaktifan setiap anggota didalam kelompok, ketidakaktifan individu tentu akan memicu terjadinya social loafing, bisa karena attribution and equity (individu menganggap anggota lain tidak berkompeten sehingga tidak perlu untuk mengeluarkan usaha yang lebih keras) seperti yang dikemukakan Latane et al., (1979) atau expected coworker performance (individu merasa usaha dari anggota kelompok yang lain akan tinggi sehingga tidak perlu mengeluarkan usaha yang lebih) dari Hart et al., (2004). Merujuk pada hasil penelitian Deborah S \& Sisilia (2017), mayoritas subjek penelitian mereka lebih senang bekerja dalam kelompok berukuran kecil.

Kategorisasi Loc internal menunjukkan sebanyak 67 mahasiswa $(65,7 \%)$ memiliki tingkat Loc internal yang rendah, 35 mahasiswa (34,3\%) memiliki locus of control internal yang tinggi. Sedangkan untuk Loc eksternal, sebanyak 48 mahasiswa $(47,1 \%)$ tergolong tinggi, dan sebanyak 54 mahasiswa $(52,9 \%)$ tergolong rendah. Perlu diingat bahwa kedua aspek ini melekat didalam diri setiap individu dengan bersifat continuum, dan perlu untuk diketahui juga bahwa individu dengan tingkat Loc internal yang tinggi cenderung lebih percaya diri dan gigih menghadapi bermacam dimensi kehidupan, karena setiap tindak tanduknya lebih diyakini disebabkan dan ditentukan oleh dirinya sendiri (Myers, 1983 dalam Sari, 2016), sebelumnya juga telah dikemukakan oleh Sceibe (1978, dalam Allen, 2005) bahwa individu dengan Loc internal tinggi cenderung lebih aktif, berusaha keras dan lebih berprestasi, serta lebih cenderung tidak menggantungkan diri kepada orang lain, banyak peneliti yang telah mengasosiasikan Loc Internal dengan upaya/usaha yang lebih aktif, hal tersebut terwujud dalam bentuk tindakan sosial dan pencapaian tujuan (Levenson, 1974).

Loc internal terbukti dapat menurunkan kecenderungan social loafing pada mahasiswa, sedangkan Loc eksternal tidak memberikan kontribusi pengaruh sama sekali, bahkan tidak berkorelasi dengan social loafing. Steven Karau \& Kipling William (1993) menganjurkan beberapa saran untuk menurunkan social loafing berdasarkan hasil meta analisis mereka pada 79 hasil penelitian, beberapa saran tersebut antara lain adalah membuat individu percaya bahwa performa mereka dapat dievaluasi baik oleh diri sendiri ataupun anggota kelompok yang lain, membuat mereka meyakini bahwa tugas kelompok yang mereka kerjakan sangat penting \& berarti untuk diselesaikan, membuat mereka yakin bahwa kontribusi yang mereka berikan akan sangat diperlukan dan sangat menunjang pada pencapaian keberhasilan serta kepuasaan kelompok (hal ini berkaitan erat dengan motivasi dan kordinasi). Robert Zajonc (1965 dalam Suryanto, Aniputra, Herdiana \& Alfian, 2012) perihal social facilitation (meningkatnya performansi individu karena kehadiran individu lain), bahwa walaupun kehadiran individu lain bisa menyalurkan bahkan meningkatkan semangat, tetapi performa dari individu itu sendiri akan tergantung pada jenis tugas yang dikerjakan.

\section{Kesimpulan}

Simpulan penelitian ini menunjukkan pengaruh Loc internal pada social loafing mahasiswa dalam penyelesaian tugas berbasis kelompok, dengan kontribusi pengaruh senilai $0,2 \mathrm{II}$ atau sebesar $2 \mathrm{I}, \%$. Loc internal terbukti dapat menurunkan kecenderungan social loafing pada mahasiswa, sedangkan Loc eksternal tidak memberikan kontribusi pengaruh sama sekali, bahkan tidak berkorelasi dengan social loafing. Saran dari peneliti adalah meningkatkan serta menguatkan Loc internal pada tiap individu dalam konteks penyelesaian tugas secara kelompok, kemudian perlunya untuk mempertimbangkan pemberian nilai yang berbeda bagi setiap individu berdasarkan tingkat keaktifan dalam kelompok, sehingga tiap individu akan lebih berupaya memberikan kontribusi terbaik yang mereka miliki, hal ini akan berdampak pada peningkatan kinerja kelompok. Kemudian perlu untuk mempertimbangkan kesesuaian antara tingkat kesulitan tugas yang akan diberikan dengan jumlah 
anggota dalam tiap kelompok, selain itu juga ada baiknya untuk mempertimbangkan jenis tugas yang akan diberikan, apakah lebih efektif diselesaikan secara kelompok atau mungkin secara individu. Saran peneliti untuk mahasiswa dianjurkan agar dalam penyelesaian tugas secara kelompok untuk membuat kesepakatan, seperti pembagian tugas dan konsekuensi yang akan diberikan bila tiap anggota kelompok tidak terlibat aktif dalam penyelesain tugas, hal ini dilakukan agar kontrol didalam kelompok tetap terjaga. Setidaknya ada tiga term favorite yang wajib untuk diingat dan perlu untuk ditekankan pada pengerjaan tugas-tugas berbasis kelompok, yaitu motivasi, kordinasi dan kontrol, baik kontrol berdasarkan hasil kesepakatan tiap anggota kelompok, maupun kontrol yang berasal dari dalam diri sendiri (internal locus of control).

\section{REFERENSI}

Allen, D. G., Weeks, K. P., \& Moffitt, K. R. (2005). Turnover Intentions and Voluntary Turnover: The Moderating Roles of Self-Monitoring, Locus of Control, Proactive Personality, and Risk Aversion. Journal of Applied Psychology, 90(5), 980-990. http://dx.doi.org/I0.1037/002I$\underline{9010.90 .5 .980}$

Abzani, A., \& Leonard, L. (2017). Pengaruh locus of control terhadap kemampuan pemecahan masalah matematika. Prosiding Diskusi Panel Nasional Pendidikan Matematika, I(I), 549-558.

Chidambaram, L., \& Tung, L. L. (2005). Is out of sight, out of mind? An empirical study of social loafing in technology-supported groups. Information systems research, 16(2), 149-168. https://doi.org//0.1287/isre.1050.005I

Deutchman, I. E. (1985). Internal-external locus of control, power and political participation. Psychological reports, 57(3), 835-843. https://doi.org//0.2466/pr0.1985.57.3.835

Duffy, M. K., \& Shaw, J. D. (2000). The Salieri syndrome: Consequences of envy in groups. Small group research, 3I(I), 3-23. https://doi.org/I0.1/77//04649640003/00I0I

Earley, P. C. (1989). Social loafing and collectivism: A comparison of the United States and the People's Republic of China. Administrative science quarterly, 565-58I. https://www.jstor.org/stable/2393567

Fini, A. A. S., \& Yousefzadeh, M. (20I I). Survey on relationship of achievement motivation, locus of control and academic achievement in high school students of Bandar Abbas (Iran). Procedia-Social and Behavioral Sciences, 30, 866-870.

Hadi, S. (2000). Metodologi penelitian. Yogyakarta: Andi Offset.

Harkins, S. G., \& Szymanski, K. ( 1989 ). Social loafing and group evaluation. Journal of personality and social psychology, 56(6), 934-94I. http://dx.doi.org/|0.1037/0022-35|4.56.6.934

Hart, J. W., Karau, S. J., Stasson, M. F., \& Kerr, N. A. (2004). Achievement Motivation, Expected Coworker Performance, and Collective Task Motivation: Working Hard or Hardly Working? I. Journal of Applied Social Psychology, 34(5), 984-1000. https://doi.org/|0.1III/j.I559-1816.2004.tb02580.x

Heller, P., Keith, R., \& Anderson, S. (1992). Teaching problem solving through cooperative grouping. Part I: Group versus individual problem solving. American journal of physics, 60(7), 627-636. https://doi.org/10.1119/1.17117

Hoigaard, R., Tofteland, I., \& Ommundsen, Y. (2006). The effect of team cohesion on social loafing in relay teams. International Journal of Applied Sport Sciences, I8(I), 59-73.

Holt, C. L., Clark, E. M., Kreuter, M. W., \& Rubio, D. M. (2003). Spiritual health locus of control and breast cancer beliefs among urban African American women. Health Psychology, 22(3), 294-299. http://dx.doi.org//0.1037/0278-6/33.22.3.294 
Howerton, D. L., Enger, J. M., \& Cobbs, C. R. (1993). Locus of control and achievement for at-risk adolescent black males. The High School Journal, 76(3), 210-214. https://www.jstor.org/stable/40364580

Ingham, A. G., Levinger, G., Graves, J., \& Peckham, V. (1974). The Ringelmann effect: Studies of group size and group performance. Journal of experimental social psychology, I0(4), 37I-384. https://doi.org/10.1016/0022-1031(74)90033-X

Ismail, N. S. (2016). Pengaruh locus of control dan hardiness terhadap stres pada mahasiswa yang menyusun skripsi. (Tesis tidak dipublikasikan). Fakultas Psikologi Universitas Airlangga, Surabaya.

Kahoe, R. D. (1974). Personality and achievement correlates of intrinsic and extrinsic religious orientations. Journal of Personality and Social Psychology, 29(6), 8|2-8|8. http://dx.doi.org// 0.1037/h0036222

Karau, S. J., \& Williams, K. D. (1993). Social loafing: A meta-analytic review and theoretical integration. Journal of personality and social psychology, 65(4), 68I-706. http://dx.doi.org/|0.1037/0022-35|4.65.4.68|

Khir, A. M., Redzuan, M. R., Hamsan, H. H., \& Shahrimin, M. I. (2015). Locus of Control and Academic Achievement among Orang Asli Students in Malaysia. International Conference on Language, Education, Humanities and Innovation 2nd. 84-90.

Kravitz, D., Kravitz, D. A., \& Martin, B. (1986). Ringelmann Rediscovered: The Original Article, Journal of personality and social psychology, 50(5), 936-94I. https://doi.org/10.1037/0022$\underline{35 \mid 4.50 .5 .936}$

Latané, B., Williams, K., \& Harkins, S. (1979). Many hands make light the work: The causes and consequences of social loafing. Journal of Personality and Social Psychology, 37(6), 822-832. https://doi.org//0.1037/0022-35/4.37.6.822

Levenson, H. (1974). Multidimensional locus of control in prison inmates. Proceedings of the Division of Personality and Society Psychology, I(I), 354-356. https://doi.org/l0.1177/0146167274001001119

Levenson, H. (198I). Differentiating among internality, powerful others, and chance. Dalam Lefcourt, H. M. (Ed.), Research with the locus of control construct, (hlm. 15-63). New York: Academic Press. https://doi.org/10.1016/C2013-0-11068-9

Piezon, S. L., \& Ferree, W. D. (2008). Perceptions of social loafing in online learning groups: A study of public university and US Naval War College students. The International Review of Research in Open and Distributed Learning, 9(2), I-17. https://doi.org//0.19173/irrodl.v9i2.484

Rotter, J. B. (1966). Generalized expectancies for internal versus external control of reinforcement. Psychological Monographs: General and Applied, 80(I), I-28. http://dx.doi.org// 0.1037/h0092976

Sari, I. Y. (2016). Pengaruh orientasi kewirausahaan dan inovasi produk terhadap kinerja ukm kota makassar. Repositori Universitas Islam Negeri Alaudin Makasar, Makassar.

Shih, C. H., Shao, C. C., \& Wang, Y. H. (2017). Study of Social Loafing and Employee Creativity. International Conference on Innovative Mobile and Internet Services in Ubiquitous Computing, $821-830$.

Simanjuntak, P. D. R., \& Eliana, R. (2017). Hubungan antara locus of control dengan social loafing mahasiswa pada tugas berbasis kelompok. Repositori Institusi Universitas Sumatera Utara, Medan.

Singh, S., Wang, H., \& Zhu, M. (20I8). Perceptions of Social Loafing During the Process of Group 
Development. Ssrn, I-27.

Sisilia, R. A. (2016). Hubungan antara self esteem dengan social loafing pada mahasiswa. Repositori Institusi Universitas Sumatera Utara, Medan.

Suryanto., Aniputra, M. G. B., Herdiana, I., \& Alfian, I. N. (20I2). Pengantar psikologi sosial. Surabaya: Pusat Penerbitan dan Percetakan Unair.

Wallston, B. S., Wallston, K. A., Kaplan, G. D.., \& Maides, S. A. (1976). Development and validation of the Health Locus of Control (HLC) Scale. Journal of Consulting and Clinical Psychology, 44(4), 580-585. http://dx.doi.org//0.1037/0022-006X.44.4.580

Webb, N. M. (1995). Group Collaboration in Assessment: Multiple Objectives, Processes , and Outcomes. Educational Evaluation and Policy Analysis, 17(2), 239-26I. https://doi.org/I0.3102/01623737017002239

Whyte, C. B. (1977). High-Risk College Freshmen and Locus of Control. Humanist Educator, I6(I), 2-5. https://doi.org/10.1002/j.2164-6163.1977.tb00177.x

Ying, X., Li, H., Jiang, S., Peng, F., \& Lin, Z. (2014). Group laziness: The effect of social loafing on group performance. Social Behavior and Personality: an international journal, 42(3), 465-47I.

Zahra, Y., Eliana, R., Budiman, Z., \& Novliadi, F. (2015). Peran Jender dan Social Loafing Tendency terhadap Prestasi Akademik dalam Konteks Pembelajaran. Psikologia: Jurnal Pemikiran dan Penelitian Psikologi, I0(I), I-9. 